\title{
Enhancing Public Access to Legal Information: A Proposal for a New Official Legal Information Generic Top-Level Domain (.OfficialLaws New gTLD)
}

I've written the following article that contains my comprehensive proposal for the creation of a new .OfficialLaws regulated official legal information gTLD by the Internet Corporation for Assigned Names and Numbers (ICANN):

Leesi Ebenezer Mitee, "Enhancing Public Access to Legal Information: A Proposal for a New Official Legal Information Generic Top-Level Domain" (2017) 23(2) European Journal of Current Legal Issues (EJOCLI) available at http://webjcli.org/article/view/562/753. Its abstract appears below.

\begin{abstract}
This article examines the use of a new legal information generic Top-Level Domain (gTLD) as a viable tool for easy identification of official legal information websites (OLIWs) and enhancing global public access to their resources. This intervention is necessary because of the existence of unofficial legal information websites with issues of reliability and the overdependence on Internet search engines (despite their limitations) as the only means of finding and accessing OLIWs. The existing findability difficulties create technical unavailability of available online legal information. This article proffers a workable solution to these problems through its proposal for the creation of regulated official legal information gTLD by ICANN. It develops a Legal Information Domain Name System (LIDNS) exclusively for the OLIWs of governments and intergovernmental organisations (IGOs) based on the proposed gTLD. The LIDNS extends the ramification of Internet governance within the ICANN framework in respect of official legal information as a universal public brand. The article argues that the gTLD will facilitate easy identification of official sources of online legal information to avoid the risk of relying on unreliable legal resources, enable direct access to OLIWs without the laborious use of Internet search engines, and enhance their findability even when the search option is used. It concludes that the resultant improved access to the available official online legal information will promote the people's right of free public access to legal information globally. This will help people to know the laws they are bound to obey (ignorance of which is no excuse), enhance justice under the right to a fair trial, and facilitate national and transnational legal research. It will also promote transparency and accountability in governance and engender the holistic actualisation of the environmental, economic, and social components of sustainable development, among other benefits.
\end{abstract}

Keywords: Right of public access to legal information; Official legal information generic Top-Level Domain gTLD; Legal information domain name system LIDNS; United Nations World Legal Information Organization UNWLIO; Public access to law as a human right; Huricompatisation; Legal informatics: Internet Corporation for Assigned Names and Numbers ICANN; Internet governance; Free access to law movement; Legal information institutes; . officiallaws gTLD

Leesi Ebenezer Mitee, HND Town Planning and LLB (Rivers State University, Nigeria); BL (Nigerian Law School, Lagos); LLM (University of Huddersfield, United Kingdom); PhD Candidate, Tilburg University Law School, The Netherlands; Chief Lecturer in Law, Institute of Legal and Global Studies, Port Harcourt Polytechnic, Rivers State, Nigeria; former legal research consultant to the United Nations Development Programme (UNDP), 1998, on a project that provided the juridical foundations for the ECOWAS Declaration of a Moratorium on Importation, Exportation and Manufacture of Light Weapons in West Africa (31 October 1998) which culminated in the ECOWAS Convention on Small Arms and Light Weapons, their Ammunition and other Related Matters 2006. I thank, immensely, the following persons for their most valuable insightful comments on the draft of this Article: Prof. Dr. Ernst M. H. Hirsch Ballin, Tilburg University and University of Amsterdam / Asser Institute, The Netherlands; and Dr. Sofia Ranchordás, Assistant Professor of Constitutional and Administrative Law at Leiden Law School, The Netherlands, and Affiliated Fellow of the Yale Information Society Project, United States; and Dr. Marc van Opijnen who is affiliated to the Publications Office of the Netherlands (UBR|KOOP). Any error is mine. Email: leesimitee@leesimitee.com; The Right of Public Access to Legal Information Website: http://accesstolegalinformation.com/

This Open-Access Article (Full Text) Link: http://webjcli.org/article/view/562/753

Right of Public Access to Legal Information Website: http://accesstolegalinformation.com/

Article Contact Email: leesimitee@leesimitee.com 